\title{
What do Flaubert, Dostoevsky and Machado de Assis have in common with neurology?
}

\author{
$\mathrm{O}$ que Flaubert, Dostoevsky and Machado de Assis têm em comum com a neurologia? \\ Bruno Kusznir Vitturi', Wilson Luiz Sanvito'
}

\begin{abstract}
The Frenchman Gustave Flaubert, the Russian Fyodor Dostoevsky and the Brazilian Machado de Assis are known for their immeasurable contributions to literature. However, what most people do not know is that all three authors suffered from epilepsy and were affected by their neurological condition in different ways. We offer a short description of how epilepsy influenced their lives, how they dealt with it and how their neurological condition was present in their novels and correspondence. Their lives are excellent examples of how intimately neurology can be entwined in art and history, and provide an important perspective on patients with epilepsy.
\end{abstract}

Keywords: neurology; epilepsy; art.

\section{RESUMO}

O francês Gustave Flaubert, o russo Fyódor Dostoevsky e o brasileiro Machado de Assis são conhecidos pela sua imensurável contribuição para a Literatura. No entanto, o que a maioria das pessoas desconhece é que os três autores sofriam de epilepsia e foram, de diferentes maneiras, afetados por sua condição neurológica. Nós fazemos uma breve descrição de como a epilepsia influenciou suas vidas, como eles lidaram com a doença e como sua condição neurológica estava presente em seus romances e correspondências. Suas vidas são excelentes exemplos de quão íntima pode ser a neurologia da arte e da história e fornecem uma importante visão sobre os pacientes com epilepsia.

Palavras-chave: neurologia; epilepsia; arte.

The Frenchman Gustave Flaubert, the Russian Fyodor Dostoevsky and the Brazilian Machado de Assis suffered from epilepsy and were affected by their neurological condition in different ways.

Gustave Flaubert (1821-1880) was the author of classic masterpieces in history such as Madame Bovary (Figure 1). In spite of his literary fame, Flaubert had epilepsy ${ }^{1}$. According to historical accounts, his first seizure occurred in 1844, stunning his parents ${ }^{1,2}$. Epilepsy was a long way from been understood, so an epileptic crisis aroused all sorts of speculation and stigmatization from the people around him. Even his father, who was a doctor, was "beside himself" and tried various therapeutic means to heal his son: "he tried unsuccessfully to bleed Gustave, he applied boiling water to Gustave's hand thus causing a painful second degree burn"3. He would try many different treatments during his life: quinine, bromides, plant infusions and drainages ${ }^{2,3}$.

His friend Maxime du Camp reported many of Flaubert's crises: "Very often, distraught and powerless to intervene, I would witness his seizures, which were indeed terrifying to

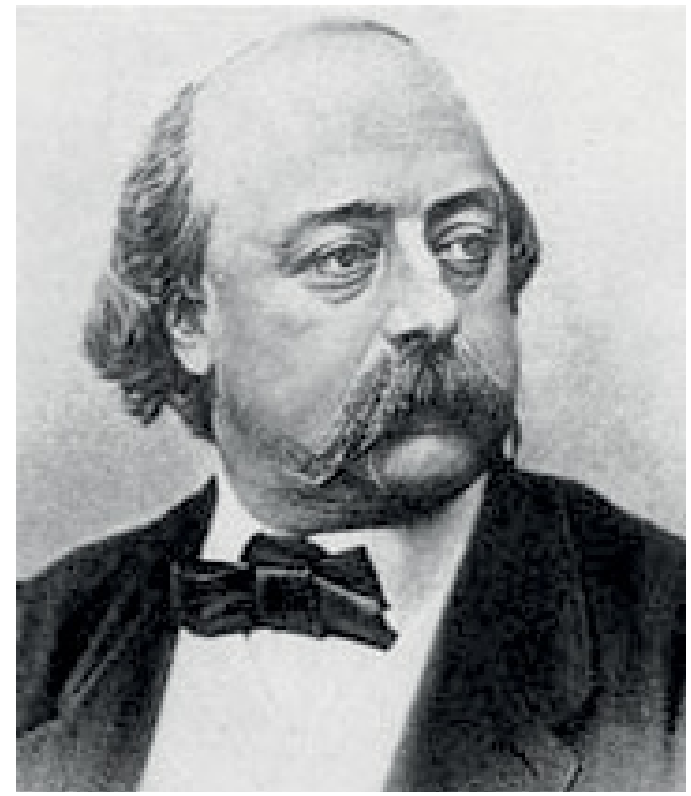

Figure 1. Gustave Flaubert (1821-1880), the author of Madame Bovary.

1Santa Casa de São Paulo, Faculdade de Ciências Médicas, Disciplina de Neurologia, São Paulo SP, Brasil;

Correspondence: Bruno Kusznir Vitturi; Disciplina de Neurologia; Rua Dr. Cesário Mota Júnior, 112 / $3^{\circ}$ andar; $01221-020$ São Paulo SP, Brasil;

E-mail:z_azul@hotmail.com

Conflict of interest: There is no conflict of interest to declare.

Received 08 July 2017; Received in final form 02 August 2017; Accepted 14 August 2017. 
see. [...] Abruptly, without any reason, Gustave would raise his hand and become very pale; [...] His eyes would be full of anxiety and he would hunch his shoulders in a distressing and discouraging movement. [...] Then the convulsion would take him over"3. Flaubert also described the epileptic auras himself: "I have a flame in my eye; everything is tinged with gold". Epilepsy became a part of his life, as did the suffering caused by it. His illness made him abandon his studies in law causing him to become increasingly isolated from people and society. He always felt embarrassed by his medical condition, and the prejudices toward the epileptic at that time were undeniable ${ }^{2,3}$. So much so, that there is no description of his convulsions in his literary output and, when Flaubert spoke about his attacks, he called them "nerve sickness" or used other euphemisms. However, it is certain that his illness had influenced his identity as a writer and it reinforced Flaubert's literary inclinations: "I have an outlet [...]. The paper is here and I am relieved", wrote Flaubert, referring to his epilepsy3.

Fyodor Dostoevsky (1821-1881), one of the most important Russian writers in history, also suffered from epilepsy (Figure 2). Dostoevsky was sentenced to four years of forced labor in a Siberian prison after being accused of distributing printed works directed against the government. However, one could say that epilepsy "saved" him - the author of The Idiot managed to convince the military, in which he was forced to serve indefinitely, that retaining an army officer with epilepsy (a mysterious disease) was extremely dangerous, and he was discharged of the army $y^{4}$. Another interesting and notable point of Dostoevsky's epilepsy was that he probably suffered from ecstatic aura, the existence of which was previously unknown. He often described sudden and unanticipated psychological states characterized by vivid memories and a pleasant sensation near ecstasy. These epileptic auras somehow justify his seminal idea that a moment of happiness is worth a lifetime ${ }^{4,5}$.

Unlike Flaubert, epilepsy was present in at least six of Dostoevsky's characters. In fact, epilepsy occupied a prominent position in his novels, in that the seizures were richly depicted and even helped in the construction of the personality of the characters ${ }^{4,5,6}$. In The Brothers Karamazov, for instance, a character with epilepsy simulates one of his crises in order to not be accused of a murder that he committed ${ }^{6}$. Dostoevsky incorporated his own suffering into his art and acknowledged the therapeutic effects that literature had on his health, although writing was repeatedly contraindicated by his doctors. Several times, Dostoevsky was skeptical about the prescribed treatment (bromides), although he had repeatedly sought the opinions of great neurologists, such as Moritz Romberg ${ }^{4,5,6}$.

Machado de Assis (1839-1908) is considered the most famous Brazilian writer (Figure 3). His seizures began in infancy and accompanied him his whole life. He probably suffered from temporal lobe epilepsy with complex partial seizures that were secondarily generalized ${ }^{7}$. Like Flaubert, Machado de Assis never felt comfortable with his epilepsy and always tried to hide it. The word "epilepsy" or its derivatives only appeared in his literary texts in the first edition of The Posthumous Memoirs of Bras Cubas, after which the word was deleted in all the other editions ${ }^{8}$. Similarly, in 1872, Machado translated a booklet, by

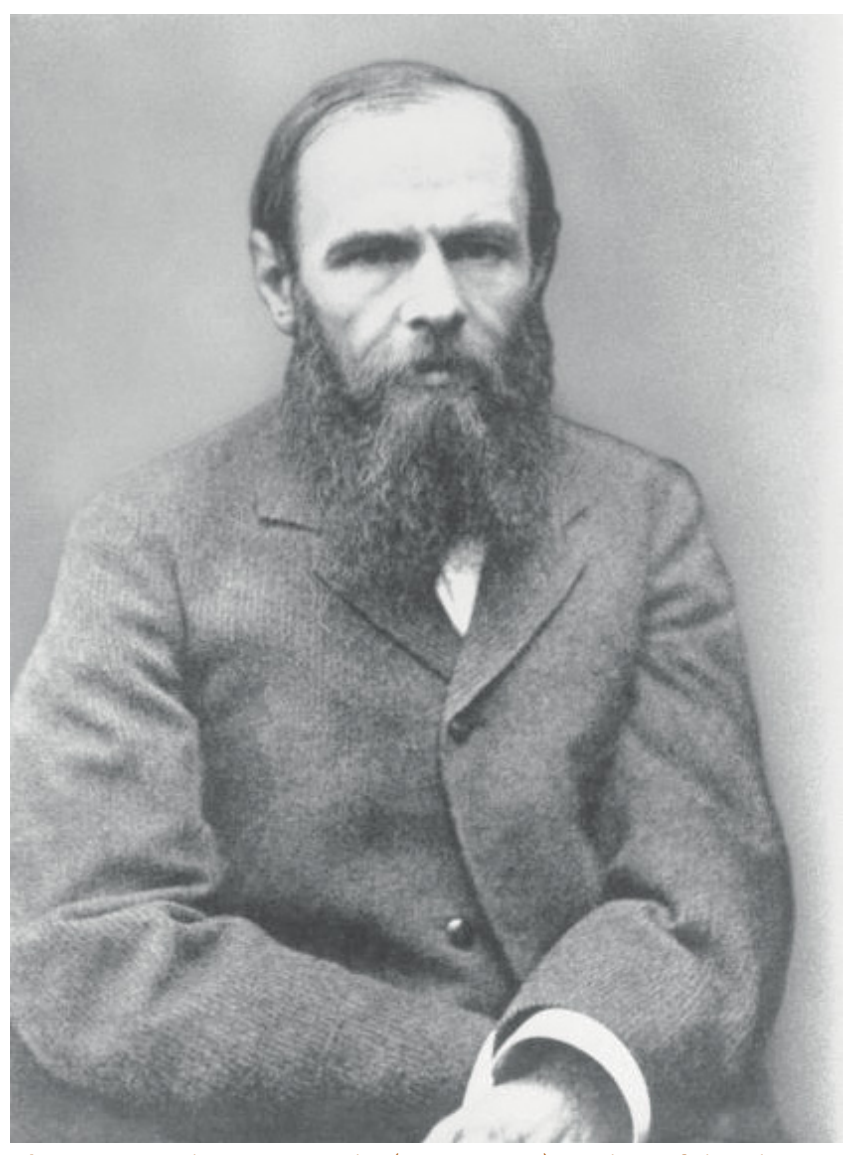

Figure 2. Fyodor Dostoevsky (1821-1881): author of the classic Crime and Punishment.

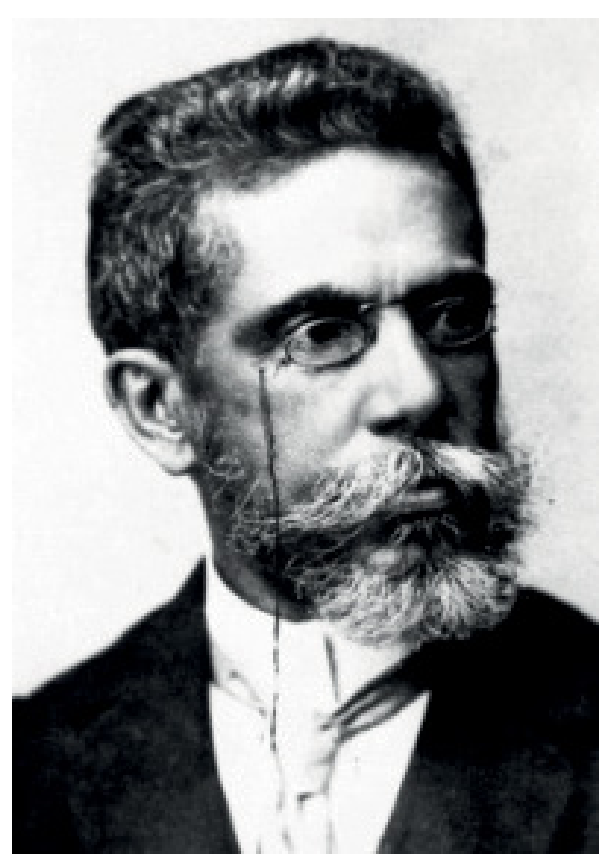

Figure 3. Machado de Assis (1839-1908): the most significant Brazilian writer 
a French doctor, Hygiene for Schools and, curiously, he did not save the word "epilepsy" here either. At that time, the ideas of the Italian neuropsychiatrist Cesare Lombroso were on the rise and epilepsy was associated with moral degeneration, insanity and even a propensity for crime ${ }^{9}$. Machado's epilepsy is only discussed in his correspondence with his friend Mario de Alencar and even then, the author of Dom Casmurro often used the euphemism "original sin" to refer to his neurological condition: "I am getting along well, except for the usual difficulties of old age, and experiencing, without any change, the original sin" ${ }^{8,9}$. Machado did not even share his neurological problem with his wife Carolina, who only discovered it when she witnessed a seizure a few months after the wedding ${ }^{7,9}$.

As in Flaubert's and Dostoevsky's cases, treatment was not able to control Machado's epilepsy so that, even though he consulted Dr. Miguel Couto, the most distinguished Brazilian physician at that time, he described himself as "a sick man without a doctor" 8,9 . When Machado discovered that his contemporary, Flaubert, also suffered from epilepsy, he wrote: "I found the same solitude and sadness, and even the same evil, as you know, the other" 9 In fact, epilepsy put Machado de Assis into a deep state of melancholy and solitude that some critics claim contributed to his artistic production ${ }^{7,8,9}$.

Epilepsy had a deep impact on the life of Flaubert, Dostoevsky and Machado de Assis. They were epileptic at a time when there was great prejudice and disinformation about the disease. Their lives are excellent examples of how intimately entwined neurology can be to art and history, and provide important insight into patients with epilepsy.

\section{References}

1. Gastaut H, Gastaut Y. La maladie de Gustave Flaubert. Rev Neurol. 1982;6-7:467-92.

2. Gastaut H, Gastaut Y, Broughton R. Gustave Flaubert's Illness: a case report in evidence against the erroneous notion of psychogenic epilepsy. Epilepsia. 1984; 25(5):622-37. https://doi.org/10.1111/j.1528-1157.1984.tb03472.x

3. Jallon P, Jallon H. Gustave Flaubert's hidden sickness. In: Bogousslavsky J, Boller F, editors. Neurological disorders in famous artists. Front Neurol Neurosci. Basel: Karger; 2005. p. 46-56.

4. Iniesta I. Epilepsy in the process of artistic creation of Dostoevsky. Neurologia. 2014;29(6):371-8. https://doi.org/10.1016/j.nrl.2011.05.002
5. Iniesta I. Epilepsy in Dostoevsky. Prog Brain Res. 2013;205:277-93. https://doi.org/10.1016/B978-0-444-63273-9.00014-9

6. Voskuil PH. Epilepsy in Dostoevsky's novels. Front Neurol Neurosci. 2013;31:195-214. https://doi.org/10.1159/000343236

7. Guerreiro CA. Machado de Assis's epilepsy. Arq Neuropsiquiatr. 1992;50(3):378-82. https://doi.org/10.1590/S0004-282X1992000300020

8. Chapman AH, Chapman-Santana M. Machado de Assis's own writings about his epilepsy: a brief clinical . Arq Neuropsiquiatr. 58(4):1153-4. https://doi.org/10.1590/S0004-282X2000000600029

9. Yacubian EM, Caboclo LO. Epilepsy and stigma: an approach to understanding through the life and works of the Brazilian writer Machado de Assis (1839-1908). Epilepsy Behav. 2011;20(3):465-70. https://doi.org/10.1016/j.yebeh.2010.12.040 